\title{
Triangulations: Choosing Ambiguity: Playful Erotic Triptychs
}

\author{
Jacqueline Turner
}

Les strophes de Jacqueline Turner nous présentent une discussion poétique d'un désir triangulaire où une voix décentrée explore de façon érotique les replis hétérosexuel et lesbien de l'érotisme incluant non seulement le corps sexuel mais aussi le corps incorporant le language, la maternité et le jeu voyeuriste qui entoure les lignes poétiques autour de jeux de mots érotiques. Turner nous offre un dialogue qui est composé, en fait, de trois voix: une vison de la dualité qui reconnaît les points centraux tout comme les extrêmes.

\author{
"would you know proposition \\ if it kissed you \\ on the back of the neck?" \\ arms wrapped around \\ her fingers here or \\ stuck yes or shy \\ why don't you call \\ erase the trace of \\ kiss
}

her she said

$i$ kissed

your dancing with him

miss a beat lip wide

slow skips

water merges fingers

scent eventual flow

whirring he says proud

she too loud stuck-on lip stick happy 
her arms around her shoulders

do you mind

kiss pressure base of spine

licks what the tongue

staves off

outside a finger touches lip

home to him on the couch

eases into that too

large kisses lips everywhere

smitten among skin

newborn soft stroke

tiny arms flung around

necks of the always loved

pulled-in cheek to chest

quiet across thighs

you suspend

ambiguous breasts

him or her or him or

slipped past

or into

mother lover wife other other

risks her mouth wet

weighs fingers

marks flesh

fold after fold after

her flexible extension

wrenches which fingers

cherub cheeks

look

like you

drinking to decide

always wanting

white silk around potential finger 
like your father you

say red of playful flesh

wet surprise folds after

not trembling you wear

green flowers

look at poetry as if

her arms around her shoulders

suspended breasts wanted

ambiguous lips

body of obsession

you felt the overwhelm

sting

or ever the narrative

of fingers through hair

kissing the rising slack action

both the boys

still wanting

her arms around her shoulder

fingers through her hair

want to kiss you

nape of neck

torn here

rejoined, threaded

you refuse to regret fingers

your hands

stay

curve her back

fingers extend again

you never simulate embrace

an abrasive edge

brush back black hair

black of black eyes pool

reaching eyelids 
except for seeing he chooses not to

littler eyes still

stare intent fingers

white $t$-shirt raises

eager mouth to breast

relaxes flannel body

too tired dreams

he wakes loud

slips in quiet

trickles wet shirt, sheets, bed

linger cold toes to warm

flat out

improbable fingers

tiny reach

swollen easily twice

crisscross stitches

vulva wow vagina

stretches steady

yaw of him and him and

inner, and then outer

literally, you said

he rubs your

fingers wide prying

lifts your hair twists to the nape

carry on skipping remember

grab a finger of thought

you read

and it comes

eating kiwis

with spoons

fingers around

back of her

nipples slip 
turning her lips

rolling into your mouth

over your teeth

and tongue bite

between neck and shoulder

arm raises tender before elbow

lick

breasts

to jut of hip

hands clasped

or released

moving

repetitive

her arms again

fingers stuck yes or shy into

rising heavy

you have

what she says

to go torn

makes you stay

flowered stress

button up blue

she fingers fabric

orange of

he loves you

fingers striping white $t$-shirt

rake of red back

he was expecting you

you say here at least at last

careful wrists

wrapped in silver

some symbol

resembles you

especially

with his helmet off 
we were too

cynical to believe in

seeking the unconditional

fingers wrap wrists

he slips into the curve

your body again

she dances the edge

holds your tongue in her mouth

moves from yes to no to

cool wrap sheets or

surprise of flannel fingers

or

still rising writhing

sheets around ears

gouge the bed

without finger tip to nail

press until you feel you slip

towards you

farther from ear

lobes suck to her

perfect perfection

silver rings in some

other language beyond

tongue

placate my desire

thrumb of womb

you could say wanting

over ringed finger

rapacious lust

like holding

your tongue in his mouth

dances she's watching fingers slide

over voyeur 
smack a red ass start

delicate dread so

far ruined but stung

grapple me a rhythm

smooth steady toward her leaning

already framed

whenever you say when

asked after and so

kneads you an increase

set off by his weakening

grammar me noun hard

into sleeping preposition

waking with those other hims

into your clasping fingers

holding perfect

feather not one regret sneezes a release

launched full speed into

you say hmm high voice non stop

one by one they edge together

slip sideways off the bed run the stairs

who gets there first

tip right side left

together

keep going

fingers scared one by one this is who gets where first 